九州大学学術情報リポジトリ

Kyushu University Institutional Repository

\title{
A Revision of the Subgenus Larandrena of the Genus Andrena of Eastern Asia (Hymenoptera, Andrenidae)
}

Xu, Huan-Li

College of Agronomy and Biotechnology, China Agricultural Unviersity

Tadauchi, Osamu

Faculty of Agriculture, Kyushu University

https://doi.org/10.5109/4652

出版情報: 九州大学大学院農学研究院紀要. 50 (2)，pp. 391-397，2005-10-01. Faculty of Agriculture, Kyushu University

バージョン：

権利関係 : 
J. Fac. Agr., Kyushu Univ., 50 (2), 391-397 (2005)

\title{
A Revision of the Subgenus Larandrena of the Genus Andrena of Eastern Asia (Hymenoptera, Andrenidae) 1, 2, 3
}

\author{
XU Huan-Li and Osamu TADAUCHI*
}

\author{
Department of Entomology, College of Agronomy and Biotechnology, \\ China Agricultural University, Beijing, 100094 China \\ * Entomological Laboratory, Faculty of Agriculture, Kyushu University, \\ Fukuoka, 812-8581 Japan \\ (Received June 24, 2005 and accepted July 26, 2005)
}

\begin{abstract}
The subgenus Larandrena of the genus Andrena of eastern Asia is revised and three species are recognized. One species, Andrena (Larandrena) geae is new to science from China and Korea, A. (Larandrena) echizenia Hirashima et Haneda and A. (Larandrena) ventralis Imhoff are recorded from China for the first time. A key to East Asian species of Larandrena is given.
\end{abstract}

\section{INTRODUCTION}

The small subgenus Larandrena was erected by LaBerge based on the North American species Andrena miserabilis Cresson in 1964. This subgenus is similar to the subgenus Parandrena Robertson (1897) except possession of the two submarginal cells in the forewings in both sexes and the male sixth sternum being reflected with apicolateral teeth. Warncke (1968) considered Larandrena to be synonymy of Parandrena due to their similarities. LaBerge and Ribble (1972) insisted to retain the both names of Larandrena and Parandrena since the two groups of bees are probably monophyletic, respectively. Hirashima and Haneda (1973) gave comments on Parandrena and Larandrena, redescribed Larandrena and recorded this subgenus from Japan with two new Japanese species. Warncke (1975) described a new species of this subgenus from Spain. Dylewska (2000) recorded A. ventralis from Poland and regared $A$. (Larandrena) fukuiana Hirashima et Haneda as a synonymy of ventralis. In Eurasian region, five species, $A$. ventralis Imhoff 1832, A. sericata Imhoff 1868, $A$. tunetana Schmiedeknecht 1900, A. (Larandrena) echizenia Hirashima et Haneda 1973, A. (Larandrena) dinizi Warncke 1975, were included in this subgenus (Gusenleitner and Schwarz, 2002). In the course of study on East Asian Andrena, we examined specimens deposited in the Institute of Zoology, Academia Sinica, Beijing and the

1 Contribution from the Entomological Laboratory, Faculty of Agriculture, Kyushu University, Fukuoka (Ser. 6, No. 17).

2 This work was supported by a Grant-in-Aid for Scientific Research of an International Scientific Research Program from the Ministry of Education, Science, Sports and Culture, Japan (No. 07041144) and (B)(2) from Japan Society for the Promotion of Science (No. 14405025)(Both of head Investigators: $\mathrm{O}$. Tadauchi).

${ }^{3}$ Results from the China-Japan Co-operative Study on "Studies on Systematics, Evolution and Biogeography of Asian Andrena (Hym., Apoidea, Andrenidae)" No.18.

* Corresponding author (E-mail: tadauchi@agr.kyushu-u.ac.jp) 
Entomological Laboratory, Kyushu University, Fukuoka. We describe one new species $A$. (Larandrena) geae from China and Korea, and record $A$. (Larandrena) echizenia and $A$. (Larandrena) ventralis from China for the first time. The holotype will be preserved in the Institute of Zoology, Academia Sinica, Beijing, China and the paratypes will be deposited in the above institute and the Entomological Laboratory, Kyushu University, Fukuoka, Japan. The terminologies in the description are followed Tadauchi and Xu (1995).

\section{Subgenus Larandrena LaBerge}

Larandrena LaBerge, 1964, Bull. Univ. Nebraska St. Mus., 4: 304-305; Hirashima \& Haneda, 1973, Mushi, 47: 70. Type species: Andrena miserabilis Cresson, 1872, by original designation.

Diagnosis. Small to medium-sized bees; facial quadrangle as broad as long; pronotum with humeral angle and ridge; propodeal corbicula well developed with complete to incomplete anterior fringes, internal area with sparse, simple hairs; propodeum finely tessellate, not roughened; three submarginal cells present; tibial scopal hairs long, simple or plumose; tibial spurs normal; metasomal terga punctate or not. Male clypeus yellow; first flagellar segment usually long; genal area angulate posteriorly; 6th sternum flat or distinctly reflexed, 7th tergum with pygidial plate not well defined.

\section{Key to species of the subgenus Larandrena in eastern Asia}

\section{Female}

1. Process of labrum moderate, trapezoidal; labrum apical to process flat; pronotum with rugulae laterally; propodeal corbicula not well formed, without anterior fringes; metasomal terga minutely punctate geae n. sp.

- Process of labrum small, triangular; labrum apical to process transversely sulcate; pronotum without rugulae laterally; propodeal corbicula well developed with complete anterior fringes; metasomal terga impunctate ... 2

2. Length $10 \mathrm{~mm}$; process of labrum larger; clypeus narrowly smooth in the middle; scutellum narrowly smooth; propodeal enclosure distinctly rugose basally; tibial scopal hairs long, simple echizenia Hirashima

- Length $9 \mathrm{~mm}$; process of labrum much smaller; clypeus broadly smooth in the middle; scutellum more broadly smooth; propodeal enclosure less rugulose basally; tibial scopal hairs long, plumose ventralis Imhoff

\section{Male}

1. First flagellar segment shorter than second one; clypeus densely punctate; propodeum with dorsal face roughened; 6 th sternum flat geae n. sp.

- First flagellar segment longer than second one; clypeus weakly and sparsely punctate; propodeum with dorsal face tessellate, not shagreened; 6 th sternum reflexed

2. Length $8-10 \mathrm{~mm}$; mesoscutum densely tessellate, opaque; scutellum with nearly posterior half finely granular; propodeal enclosure rugulose basally; 6th sternum slightly reflexed, apicolateral angles rounded echizenia Hirashima et Haneda

- Length about or less than $8 \mathrm{~mm}$; mesoscutum weakly tessellate, smooth and shiny 
posteriorly; scutellum nearly entirely smooth and shiny; propodeal enclosure less rugulose basally; 6th sternum distinctly reflexed, apicolateral angles tooth-like

ventralis Imhoff

\section{Andrena (Larandrena) geae n. sp.}

(Fig. 1: A-E)

Female. BL 8.2-11.0 mm, WL 7.0-7.5 mm $(n=20)$.

Color. Flagellum reddish brown beneath; mandible with apical half or less reddened; wing membranes hyaline, veins and pterostigma yellowish brown; tibial spurs testaceous; posterior depressions of metasomal terga reddish brown.

Pubescence. Hairs on head moderately dense, pale white to yellow; those on clypeus $300-400 \mu$; those on vertex $400 \mu$, yellow; those on genal area 200-500 ; facial fovea bright brown. Hairs on thorax sparse to dense, yellow to whitish; those on mesoscutum $300-400 \mu$, sparse, yellowish; those on scutellum and metanotum $400 \mu$, dense, yellow; those on mesepisternum 400-700 $\mu$, whitish; propodeal corbicula developed with well

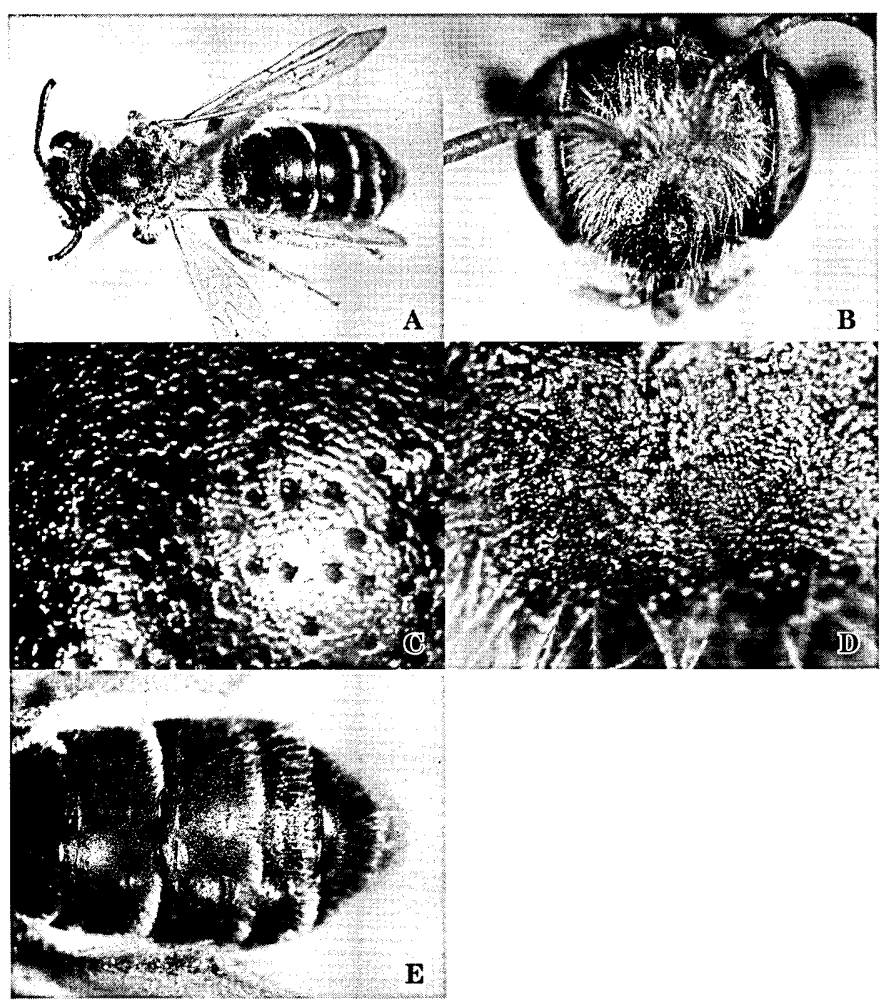

Fig. 1. A-E. Andrena (Larandrena) geae n. sp. Female A: general habitus; B: head in frontal view; C: mesoscutum; D: propodeum; E: metasomal terga. 
arranged dorsal fringes, anterior fringes lacking, internal area with sparse, simple hairs; trochanteral floccus perfect, whitish; femoral floccus dense; tibial scopal hairs long, simple, whitish. Hairs on metasomal terga short and sparse, whitish; terga 2-4 with white hair bands, which interrupted on tergum 2 medially; caudal fimbria yellow mixed with white laterally; sterna $2-5$ with incomplete whitish subapical fimbriae.

Structure. Head: HL/HW=0.82. HW: MsW: $\mathrm{MtW}=2.7: 2.7: 2.9$. Vertex short, densely tessellate. OOD: POD: $\mathrm{OCD}=0.6: 0.3: 0.15 . \quad F L 1=F L 2+3$, FL2=FL3, FL3 broader than long, intermediate segments about quadrate. Eyes with inner margins subparalleled. Facial fovea narrow, extending to below a level at lower margin of antennal fossae, close to eye, $\mathrm{FVL}=1.1 \mathrm{~mm}, \mathrm{FVW}=0.2 \mathrm{~mm}$. Supraclypeal area finely tessellate, dulled by minute PP. Face above antennal fossae with weak longitudinal rugulae and obscure interrugal PP. Facial quadrangle as long as broad (about 1.8: 1.8). Clypeus nearly flattened, weakly tessellate and broadly shiny medially, surface with shallow, sparse large $\mathrm{PP} \phi 20-30 \mu$, IS $=1-2$, smaller and denser PP on extreme angle, median area irregularly impunctate, $\mathrm{CPL}=0.8 \mathrm{~mm}$. Process of labrum moderate, trapezoidal, entire apically. Labrum apical to process with median cristae. Lower paraocular area weakly tessellate, shiny with crowded $\mathrm{PP} \phi 20 \mu$, IS $<0.5$. Malar space linear. Genal area broader than eye, GW: $\mathrm{EW}=0.7$ : 0.6 , surface finely tessellate, narrowing shiny with minute PP near eye. Mesosoma: pronotum with humeral angle and weak ridge, space between ridge and posterior pronotal lobe with several rugulae, dorsal surface densely reticularly shagreened. Mesoscutum and scutellum densely tessellate marginally, broadly and weakly tessellate medially, surface shiny with sparse small PP, IS $=1-2$. Propodeal enclosure densely tessellate apically, weakly regulate basally with short rugulae; dorsal face of propodeum shagreened by coarse tessellation. Mesepisternum densely tessellate with obscure PP. Vein 1st $m$-cu meeting second submarginal cell at basal two-thirds of cell. Metasoma: Metasomal terga weakly tessellate, broadly shiny; tergum 1 with minute PP, IS $=1-2$; tergum 2 with dense minute $\mathrm{PP}, \mathrm{IS}=1$ except apical area; tergum 3 with weak, obscure minute PP; tergum 4 nearly impunctate; posterior depressions of terga well indicated; pygidial plate $\mathrm{V}$-shaped with rounded apex, internal area with weak triangular area. Sterna 2-5 weakly tessellate, shiny, impunctate basally, weakly punctate apically.

Male. BL $7.0-8.7 \mathrm{~mm}$, WL $6.3-7.5 \mathrm{~mm}(\mathrm{n}=4)$.

Color. Flagellum reddish brown beneath; clypeus yellow; mandible with apical third or more reddened; wing membranes subhyaline, veins and pterostigma reddish brown; tibial spurs yellowish; posterior depressions of metasomal terga dark reddish brown.

Pubescence. Hairs on head dense, whitish to light brown; those on clypeus $300-600 \mu$, whitish; those on face along inner margin of eye and genal area outer margin of eye light brown; those on vertex 400-600 $\mu$, dull yellow. Hairs on thorax dense, whitish to fulvous; those on mesoscutum and scutellum 500-600 $\mu$, fulvous; those on mesepisternum 600-700 $\mu$, whitish. Hairs on metasomal terga rather short and sparse, terga 2-4 with weak, short whitish apical fasciae; sterna $2-5$ with short, complete whitish subapical fimbriae.

Structure. Head: $\mathrm{HL} / \mathrm{HW}=0.76$. $\mathrm{HW}: \mathrm{MsW}: \mathrm{MtW}=2.5: 2.0: 2.2$. Vertex as in female. OOD: POD: $\mathrm{OCD}=0.6: 0.4: 0.15$. FL1 $<$ FL2, FL2 and following segments distinctly longer than broad. Eyes with inner margins subparalleled. Supraclypeal area and face above antennal fossae sculptured as in female. Facial quadrangle broader than long (about 1.7: 
1.5). Clypeus flattened, shiny with shallow and weak $\operatorname{PP} \phi 20 \mu, \mathrm{IS}<1 ; \mathrm{CPL}=0.7 \mathrm{~mm}$. Process of labrum truncate, thickened and weakly emarginate apically, surface smooth and shiny. Mandibles long, decussate. Lower paraocular area as in female. Malar space linear. Genal area broad, angulate posteriorly, GW: $\mathrm{EW}=0.8: 0.7$, surface finely tessellate with obscure PP. Mesosoma: Pronotum with sharp humeral angle and ridge, space between ridge and posterior lobe with paralleled rugulae. Thoracic form and sculpture similar in female, occasionally mesoscutum and scutellum densely tessellate, not shiny. Vein 1st $m-c u$ meeting second submarginal cell at middle of cell. Metasoma: Metasomal terga weakly tessellate, broadly shiny; tergum 1 nearly impunctate or with obscure microscopic PP; tergum 2 with microscopic PP, IS $=1-2$, terga 3-5 nearly impunctate; posterior depressions of terga moderately indicated. Sterna $2-5$ weakly tessellate, shiny with scattered microscopic PP; sternum 6 flat, not emarginate apically.

Type material. Holotype female, Beijing, China, 11. iv. 1977 (Y-r. Wu). Paratypes: CHINA, Beijing: 1 male, 27. iii. 1950; 2 females, 11. iv. 1950; 1 female, 8. v. 1950 (L-y. Wang); 1 male, 2. iv. 1952; 2 females, 13-15. vi. 1953; 9 females and 1 male, 10-23. iv. 1963 (S-m. Ge); 1 female, 24. iv. 1973 (S-f. Wang); 1 male, 11. iv. 1978 (Y-s. Shi). Hebei Province: 3 females, Changli, 28. iv. 1962 (T-r. Chen); 1 female, Beidaihe, 3. v. 1962 (T-r. Chen). Liaoning Province: Dalian: 1 male, 9. iv. 1961 (Y-l. Chen); 1 female, 16. v. 1962 (T-r. Chen). KOREA: 1 female, Kojo, 14. v. 1941 (M. Yamada).

Remarks. This species is similar to Andrena echizenia Hirashima et Haneda. But it can be separated from echizenia by the mesoscutum very weakly tessellate and shiny, the metasomal terga more or less punctate, the female trapezoidal labral process and the pronotum with lateral rugulae and the male 6th sternum flat.

Distribution. China (Beijing, Hebei, Liaoning Provs.); Korea (north Korea).

Flight records. Female: mid April to mid June. Male: late March to mid April.

Floral associations. China: collected on Prunus spp., Pyrus pyrifolia var. culta. Malus domestica; Korea: collected on Malus domestica.

\section{Andrena (Larandrena) echizenia Hirashima et Haneda}

Andrena (Larandrena) echizenia Hirashima et Haneda, 1973, Mushi, 47: 71-72 [female \& male, Japan]; Tadauchi et al., 2001, Esakia, (41): [in URL].

Specimens examined. Holotype female (Type No. 2022, Kyushu Univ.), Shinkawana, Ohno, Fukui Pref., Honshu, Japan, 28. iii. 1972 (Y. Haneda). Other material: CHINA, Jilin Province: 1 male, Jilin City, 16. vi. 1965 (P-y. Wang).

Remarks. This species is very similar to Andrena ventralis Imhoff. But it is characterized by the female with the clypeus narrowly smooth in the middle, the propodeal enclosure with basal portion weakly wrinkled, the male with 6th sternum slightly reflexed.

Distribution. China (new record, Jilin Prov.); Japan (Hokkaido, Honshu).

Flight records. Female: late March to early May: Male: late March to mid June.

Floral association. China: Pyrus sp. Japan: Salix spp. 


\section{Andrena (Larandrena) ventralis Imhoff}

Andrena ventralis Imhoff, 1832, Isis (Oken) Jena: 1206-1207 [female and male, Switzerland].

Andrena (Larandrena) ventralis: Gusenleitner and Schwarz, 2002, Entomofauna, suppl., 12: 810-811[remarks].

Andrena rufiventris Eversmann, 1852 (nec Andrena rufiventris Lepeletier, 1841), Bull. Soc. Nat. Moscou, 25: 32 [E-European Russia].

Andrena mutabilis Morawitz, 1866 (nec Andrena mutabilis Pérez, 1895), Hor. Soc. ent. Ross., 4: 18 [new name for Andrena rufiventris Eversmann, 1852].

Andrena (Larandrena) fukuiana Hirashima et Haneda, 1973, Mushi, 47: 72-73 [female \& male, Japan]; Tadauchi et al., 2001, Esakia, (41): [in URL].

Specimens examined. Holotype female of fukuiana (Type No. 2023, Kyushu Univ.), Shinkawana, Ohno, Fukui Pref., Honshu, Japan, 28. iii. 1972 (Y. Haneda). Other material: CHINA, Beijing: 2 males, 12. iv. 1936; 2 males, 12-28. iii. 1965 (Y-h. Han). Shandong Province: 2 males, 8-13. iii. 1935.

Remarks. This species is very similar to A. echizenia, but it can be separated from echizenia by the smaller size, the female clypeus broadly smooth in the middle, the propodeal enclosure less wrinkled basally and the male 6th sternum distinctly reflexed apically.

Distribution. China (new record, Beijing, Shandong Prov.); Japan (Honshu); middle to south Europe; European Russia; Turkey; Central Asia.

Flight records. Female: late March to early April. Male: eraly March to mid April.

Floral association. Salix spp.

\section{ACKNOWLEDGEMENT}

We are grateful to Prof. Emeritus Y. Hirashima and Prof. Emeritus J. Yukawa of Kyushu University, Fukuoka, and Prof. Wu Yan-ru of Institute of Zoology, Academia Sinica, Beijing for their various help.

\section{REFERENCES}

Dylewska, M. 2000 Keys for the identification of Polish insects, XXIV Hymenoptera, Apidae, Andrenidae. Polish Ent. Soc., 68: 1-152 (In Polish)

Gusenleitner, F. and M. Schwarz 2002 Weltweite Checkliste der Bienengattung Andrena mit Bemerkungen und Ergänzungen zu paläarktischen Arten (Hymenoptera, Apidae, Andreninae, Andrena). Entomofauna, Suppl., 12: 1-1280

Hirashima, Y. and Y. Haneda 1973 New or little known species of the genus Andrena from Japan (Hymenoptera, Andrenidae). Mushi, 47: 67-73

Imhoff, L. 1832 Entomologica. Isis (Oken) Jena: 1198-1208

LaBerge, W. E. 1964 Prodromus of American bees of the genus Andrena (Hymenoptera, Apoidea). Bull. Univ. Nebraska State Mus., 4: 279-316

LaBerge, W. E. and D. W. Ribble 1972 A revision of the bees of the genus Andrena of the Western Hemisphere. Part V. Gonandrena, Geissandrena, Parandrena, Pelicandrena. Trans. Amer. Ent. Soc., 98: 271-358

Tadauchi, O. and H-l. Xu 1995 A revision of the subgenus Simandrena of the genus Andrena of 
eastern Asia with a key to Palaearctic species (Hymenoptera, Andrenidae). Esakia, (35): 201-222

Tadauchi, O., A. Dawut and H. Inoue 2001 On image database file HANABACHI based on the Japanese bees. Esakia. (41): 149-154. URL: http://konchudb.agr.agr. kyushu-u.ac.jp/ hanabachi/

Warncke, K. 1968 Die Untergattungen der westpaläarktischen Bienen-gattung Andrena F. Mem. Est. Mus. Zool. Univ. Coimbra, (307): 1-111

Warncke, K. 1975 Die Bienengattung Andrena F., in Iberien (Hym. Apidae). Teil A. Eos, 49: 293-314 